Central Washington University

ScholarWorks@CWU

All Faculty Scholarship for the College of the Sciences

$12-2013$

\title{
Glacier slip and seismicity induced by surface melt
}

Peter L. Moore

J. Paul Winberry

Neal R. Iverson

Knut A. Christianson

Sridhar Anandakrishnan

See next page for additional authors

Follow this and additional works at: https://digitalcommons.cwu.edu/cotsfac

Part of the Geology Commons, Geomorphology Commons, Geophysics and Seismology Commons, Glaciology Commons, Hydrology Commons, and the Tectonics and Structure Commons 


\section{Authors}

Peter L. Moore, J. Paul Winberry, Neal R. Iverson, Knut A. Christianson, Sridhar Anandakrishnan, Miriam Jackson, Mark E. Mathison, and Denis Cohen 
Publisher: GSA

Journal: GEOL: Geology

Article ID: G34760

\section{Glacier slip and seismicity induced by surface melt}

2 Peter L. Moore ${ }^{1}$, J. Paul Winberry ${ }^{2}$, Neal R. Iverson ${ }^{1}$, Knut A. Christianson ${ }^{3,4}$, Sridhar

3 Anandakrishnan ${ }^{4}$, Miriam Jackson ${ }^{5}$, Mark E. Mathison ${ }^{1}$, and Denis Cohen ${ }^{1}$

$4{ }^{I}$ Department of Geological and Atmospheric Science, Iowa State University, Ames, Iowa 50011,

$5 \quad U S A$

$6 \quad{ }^{2}$ Department of Geological Sciences, Central Washington University, Ellensburg, Washington

7 98926, USA

$8 \quad{ }^{3}$ Physics Department, St. Olaf College, Northfield, Minnesota 55057, USA

$9 \quad{ }^{4}$ Department of Geosciences, Penn State University, University Park, Pennsylvania 16802, USA

$10{ }^{5}$ Norwegian Water Resources and Energy Directorate, NO-0301 Oslo, Norway

\section{ABSTRACT}

12 Many of the key processes governing fast glacier flow involve interaction between a

13 glacier and its basal hydrological system, which is hidden from direct observation. Passive

14 seismic monitoring has shown promise as a tool for remotely monitoring basal processes, but

15 lack of glacier-bed access prevents clear understanding of the relationships between subglacial

16 processes and corresponding seismic emissions. Here we describe direct measurements of basal

17 hydrology, sliding, and broadband seismicity made in a unique subglacial facility in Norway

18 during the onset of two summer melt seasons. In the most pronounced of these episodes, rapid

19 delivery of surface meltwater to the bed briefly enhanced basal slip following a period of

20 elevated high-frequency seismic activity related to surface crevassing. Subsequent ground tilt

21 derived from ultra-long period seismic signals was associated with subglacial bedrock

22 deformation during transient pressurization of the basal hydraulic system. These signals are

23 interpreted to represent hydraulic jacking as the supply of water to the bed exceeded the capacity 
Publisher: GSA

Journal: GEOL: Geology

Article ID: G34760

24 of the hydraulic system. Enhanced slip terminated 2.5 hours after it started when ice-bed

25 decoupling or increased connectivity in the basal cavity network relieved cavity overpressure.

26 The results support theoretical models for hydraulic jacking and suggest that bed geometry plays

27 a key role in limiting the longevity of melt-induced speed-up.

\section{INTRODUCTION}

Recent field measurements increasingly challenge the longstanding view that glacier

30 motion is a slow and steady process dominated by viscous drag. Field and geodetic

31 measurements in Greenland show rapid fluctuations in ice motion on timescales of minutes to

32 days, accommodated primarily by basal sliding (Shepherd et al., 2009; Bartholomew et al.,

33 2012). Large changes in sliding speed are usually associated with the input or accumulation of

34 surface meltwater at the glacier bed during the summer melt season. Enhanced sliding can last

35 from hours to months, but in some cases does not occur at all (e.g., Harper et al., 2002),

36 depending on the glacier's capacity to store or evacuate the influx of water. A glacier's dynamic

37 response to increased surface melting in a warming climate can therefore range from none to

38 small and temporary and further to large and sustained, with substantial implications for sea level

39 change. While conceptual models for the link between glacier hydrology and dynamics exist-

40 and most have at least some observational validation - the inaccessibility of glacier beds renders

41 many of these models fraught with uncertainty (Harper et al., 2002).

42 Passive seismic instrumentation has the potential to allow efficient, remote monitoring of

43 some of the key processes that affect glacier dynamics, including those related to the evolution of

44 glacial hydrology. The majority of glacier-related seismicity has been attributed to one of five

45 mechanisms: crevassing at the surface (Walter et al., 2009) and iceberg-calving at floating

46 margins (Tsai et al., 2008), and basal ice fracture (Walter et al., 2010), stick-slip sliding 
Publisher: GSA

Journal: GEOL: Geology

Article ID: G34760

47 (Anandakrishnan and Bentley, 1993; Zoet et al., 2012), and hydraulic resonance (Winberry et al.,

48 2009) at the bed. Seismological analysis of the signals produced by glaciers helps to constrain

49 these source mechanisms, but difficulty in directly observing the glacier bed has prevented

50 independent verification of the basal sources and the information that can be gained from them.

To better constrain the origins of seismicity accompanying basal sliding and hydrological

52 routing, we conducted subglacial experiments at Engabreen, a temperate outlet glacier of the

53 Svartisen Ice Cap in northern Norway $\left(66^{\circ} 40^{\prime} 12^{\prime \prime} \mathrm{N}, 13^{\circ} 47^{\prime} 24\right.$ " E) that allows direct human

54 access to the glacier bed. Tunnels in the rock beneath the glacier intersect the glacier bed at

55 several locations ("intakes") where basal meltwater is captured and routed to a hydroelectric

56 power generating facility. One of these tunnels has been reserved for subglacial research

57 ("research tunnel": RT in Fig. 1) and allows direct access to the bed beneath $200 \mathrm{~m}$ of sliding,

58 temperate ice. Water pumps, hoses and a water heater are used to create a workspace and make

59 measurements in a temporary cavity melted into the basal ice. The rock tunnels within the

60 underlying bedrock permit additional instrumentation to be deployed within $\sim 7 \mathrm{~m}$ of the base of

61 the glacier.

\section{METHODS}

63 Between March, 2010, and June, 2011, instruments were deployed at the base of the

64 glacier in and around the research tunnel to measure basal water pressure, bed normal stress,

65 basal shear stress, sliding displacement, ice acceleration, seismicity and acoustic emissions. A

66 brief summary of the instruments and methods is provided here, while additional details,

67 specifications, and illustrations are provided in the online data repository.

An instrumented rock panel (the "friction panel"), installed flush with the glacier bed

69 through a vertical access shaft, measured shear and normal force on a $0.3 \mathrm{~m}$ diameter circular 
Publisher: GSA

Journal: GEOL: Geology

Article ID: G34760

70 granite tablet supported by low-friction thrust bearings (Iverson et al., 2003; Cohen et al., 2005).

71 Water pressure transducers were mounted at the base of the granite tablet and communicated

72 hydraulically with basal water through $10 \mathrm{~mm}$ porous discs embedded in the granite. Shear stress

73 was measured with custom-built vibrating-wire load cells positioned in two orthogonal positions

74 pressing against the downglacier edge of the granite tablet. Similar load cells were mounted

75 vertically adjacent to the granite tablet to measure normal force on the bed. An acoustic

76 emissions (AE) sensor was bonded to the base of the upper platen and logged with a dedicated

77 computer system (Cohen et al., 2006). Basal motion of the glacier was measured with

78 extensometers attached by kevlar-sheathed cables passing through rock boreholes to passive

79 anchors embedded within the basal ice or at the ice/bed interface. Anchors were either manually

80 embedded in basal ice during installation of the rock panel or were left on the glacier bed to be

81 entrained in ice as the installation cavity closed due to ice creep.

82 Broadband seismometers were installed at several locations within the subglacial tunnel

83 system, including sites at the base of the rock panel in the vertical shaft area (this station is

84 hereafter referred to as VS), along the tunnel wall on the opposite side of the tunnel, and in the

85 entrance to the horizontal shaft (see locations in Figs. DR1-2 of the online data repository). The

86 seismic stations consisted of Guralp 3-T sensors connected to Reftek RT130 data recorders

87 logging at $500 \mathrm{~Hz}$. Stations were powered by lead acid batteries and were installed directly on

88 the floor of the tunnel. The internal clocks of the data loggers were synced using Global

89 Positioning Systems at the beginning and end of the experiment by transporting the units to the

90 tunnel entrance. Ultra-long-period signals extracted from the 100-35,000 second band were

91 converted to ground tilt following Wiens et al. (2005) and Genco and Ripepe (2010) (See online

92 data repository for details). 
Publisher: GSA

Journal: GEOL: Geology

Article ID: G34760

93 Water discharge was monitored with gaging stations in the tunnels downstream of the

94 subglacial intakes. Changes in discharge through the intake tunnel reflect the meltwater supply,

95 modulated by the hydraulic capacity of the subglacial drainage system (Lappegard et al., 2006).

96 An automated weather station recording surface air temperature and precipitation was situated on

97 a nunatak (Skjæret) $7 \mathrm{~km}$ east of the subglacial access.

$98 \quad$ RESULTS

99 A six-day period of above-freezing temperatures, beginning on May 8, 2011, resulted in a

100 substantial increase in the amount of meltwater delivered to the glacier bed (Fig. 2). Prior to May

101 10, meltwater discharge through the subglacial tunnels was derived mostly from surface

102 snowmelt delivered through subaerial intakes (via Fonndalstunnelen, labeled F in Fig. 1).

103 However, beginning on May 10, water flux from the subglacial intakes began to increase (Fig.

104 2). The rate of change in subglacial discharge peaked during events on May 11 and 16 resulting

105 in discharge doubling within one hour (the discharge measurement interval was $1 \mathrm{~h}$ ). In each

106 case, ultra-long period seismicity began immediately prior to the increase in discharge. Though

107 seismometers are typically used to measure deformation associated with the passing of seismic

108 waves, large signals in this ultra-long period band are more often associated with ground tilt, as

109 explained below. Tilt derived from this ultra-long-period seismic signal is shown in Figure 2B

110 (see online data repository and Figs. DR4,DR7-9). These coupled hydraulic and tilt events as

111 well as an analogous one detected on May 15, 2010, were expressed similarly in instrumental

112 measurements. The instrument array was most complete during the event on May 11, 2011, so

113 we focus here on results from that event but provide data from the other two events in the online 114 repository for comparison. 
Publisher: GSA

Journal: GEOL: Geology

Article ID: G34760

115 Instrumental and seismic measurements in the research tunnel on May 11, 2011 indicate a

116 complex subglacial response to meltwater forcing lasting $\sim 2.5 \mathrm{~h}$ (Fig. 3). Normal stress and

117 water pressure at the friction panel declined rapidly by $200 \mathrm{kPa}$ at $\sim 04: 00$, reached minimum

118 values at 05:00 and then began a gradual increase of $400 \mathrm{kPa}$, reaching a maximum in excess of

$1191800 \mathrm{kPa}$ (local ice-overburden pressure) around 12:00 (Fig. 3A). During the initial decline,

120 normal stress that the glacier exerted on the bed decreased slightly more than water pressure,

121 resulting in a decline in effective stress (normal stress minus water pressure).

122 During the same period, shear stress on the panel exhibited small fluctuations of 1-2 kPa

123 (Fig. 3B). An initial rise in shear stress during the decline in water pressure was punctuated by a

124 decrease of $2 \mathrm{kPa}$ in only 5 min beginning at $04: 19$, followed by more subdued fluctuations.

125 Changes in the rate of acoustic emissions from the panel correlated strongly with these changes

126 in shear stress (Fig. 3C). The most distinct local maxima in shear stress and AE rate (04:20 and

127 06:29) were separated by just over two hours and bracketed a period when basal water pressure

128 and normal stress reached minimum values.

129 Direct measurements of basal motion indicate that changes in the character of basal slip

130 occurred during the interval between 04:20 and 06:29 but that slip was not abrupt. Displacement

131 of an anchor installed at the ice-bed interface was negligible prior to 05:00 and after 06:29. In the

132 intervening period, one millimeter of gradual slip was recorded (Fig. 3B).

133 Changes in seismic activity in both high and low frequency ranges accompanied the basal

134 water pressure and slip event. Two different aspects of the records from station VS are shown in

135 Figure 3D, decomposed into discrete high-frequency event rate and ground tilt derived from the

136 ultra-long-period (ULP; 100-35,000 s) band. The initiation of the May 11 pressure and slip event

137 immediately followed a brief increase in discrete seismic events in the $5-40 \mathrm{~Hz}$ frequency band 
Publisher: GSA

Journal: GEOL: Geology

Article ID: G34760

138 (Fig. 3D), a range characteristic of slip and fracture processes (e.g., Roux et al., 2008). Analysis

139 of the phase relationships between vertical and horizontal channels in these events indicates that

140 they were dominated by Rayleigh-wave energy (see also Fig. DR6). A ULP tilt signal appearing

141 in horizontal channels but not in the vertical channel commenced shortly thereafter, coinciding

142 approximately with the initial decrease in water pressure and increase in shear stress at the panel

143 (Fig. 3D). A second broadband instrument $10 \mathrm{~m}$ away (station 001 in Fig. DR1) showed a similar

144 response (Fig. DR4), indicating that the ULP signals were not instrumental artifacts. Correlation

145 between changes in tilt in this and other events and changes in stress and water pressure on the

146 bed suggest a relationship between these variables.

\section{DISCUSSION}

148 The basal hydraulic system for a temperate glacier is adjusted to prior hydrological 149 conditions (Iken and Bindschadler, 1986; Harper et al., 2002). When water supply to the bed

150 increases rapidly, water pressure can rise in hydraulically-connected basal passages and locally

151 lift the glacier. Uplift allows pockets of over-pressurized water access to other portions of the

152 bed and can lead to opening of new passages for more efficient evacuation of water. This process

153 can transiently alter the balance of forces at the glacier bed and increase sliding velocity in a

154 process termed "hydraulic jacking" (Iken and Bindschadler, 1986).

155 The basal stress and water pressure measurements are consistent with the expected

156 mechanical response to meltwater forcing in a region of the bed that is initially unconnected to

157 the active basal hydrological system. When pressurized water in adjacent cavities lifts the ice,

158 local water pressure and normal stress in an unconnected portion of the bed decline until water

159 invades and pressurizes the gap created by the uplift (Murray and Clarke, 1995; Lappegard et al., 160 2006). 
Publisher: GSA

Journal: GEOL: Geology

Article ID: G34760

The initial rise and abrupt decline in shear stress on the friction panel during declining

162 effective stress is unexpected in a frictional system at limiting equilibrium (e.g., rock debris

163 embedded in basal ice frictional sliding over clean bedrock (Iverson et al., 2003)). However,

164 these fluctuations in shear stress can be explained by temporary mobilization of an otherwise

165 static layer of sediment that divided ice from the friction panel: such a debris layer has been

166 occasionally observed at the bed during instrument installation (Fig. DR3C).

167 The temporal evolution of the AE rate and the magnitude-frequency distribution of

168 acoustic events (as characterized by the power-law slope of this distribution, or the $b$-value) are

169 also consistent with frictional slip during this period (Fig. 3C). Prior experimental results for

170 sliding on rock interfaces indicate that mounting stress toward failure of an initially locked

171 interface is characterized by a large increase in the $\mathrm{AE}$ rate and a corresponding decrease in $b$ -

172 value (Lei et al., 2004). Rupture and slip of the stressed interface then causes a rapid decline in

173 AE rate and gradual increase in $b$-value, consistent with our panel measurements.

174 Despite strong evidence for activation of local frictional slip by hydraulic jacking, there

175 was no seismic expression consistent with stick-slip at station VS, $4 \mathrm{~m}$ below the friction panel,

176 nor at any other seismometer (the lack of seismicity attributable to stick-slip is a conspicuous

177 result, but requires a detailed analysis that is beyond the scope of the present paper). The discrete

178 high-frequency events were dominated by Rayleigh-wave energy, indicating an origin at or near

179 the glacier's free upper surface (see Fig. DR6). These observations are consistent with well-

180 documented characteristics of crevasse opening and propagation sources (Mikesell et al., 2012).

181 The peak in event rate just prior to the onset of the water pressure and slip episode thus may

182 reflect enhanced crevasse propagation, possibly allowing delivery of surface meltwater to the

183 bed. 
Publisher: GSA

Journal: GEOL: Geology

Article ID: G34760

The seismometer-derived tilt shown in Figure 3D (also see similar traces in Figs. DR4,

185 DR7, and DR9) is reminiscent of that recorded by broadband seismometers on volcanoes and

186 validated with independent tiltmeter measurements (Wiens et al., 2005; Genco and Ripepe,

187 2010). Like those measurements, the ULP signals we observed appeared in both of the

188 seismometers' horizontal channels but were essentially absent in the vertical (Fig. 3D). The

189 simultaneous appearance of these signals in multiple stations beneath Engabreen and their close

190 association with each of the major melt events indicates that they are an essential feature of these

191 events. Our interpretation is that these tilt events represent ground deformation due to local

192 changes in the load applied by the overlying glacier and its hydraulic system. Indeed, hydraulic

193 jacking occurs when pressurization of basal cavities transiently applies a net force on the glacier

194 base directed upward and in the downglacier direction. Deformation of the underlying rock due

195 to the opposing force of pressurized water pushing back on the bed is an expected consequence

196 of the jacking process.

\section{SUMMARY AND CONCLUSIONS}

198 The subglacial seismic and instrumental measurements during the morning of May 11,

1992011 (and similarly on May 16, 2011 and May 15, 2010) are consistent with the following

200 conceptual model of water-supply-driven adjustment of the basal hydraulic system at the onset of

201 the melt season. When water introduced to the glacier bed from the surface overwhelmed the

202 existing system of linked basal cavities, cavity pressurization and hydraulic jacking activated

203 enhanced basal slip, locally mobilizing sliding on a frictional interface and enlarging the cavity

204 openings. Though small, the brief acceleration associated with jacking must have been

205 accompanied by a net force applied against the bed, manifested here as seismometer-derived tilt 
Publisher: GSA

Journal: GEOL: Geology

Article ID: G34760

206 signals. Enhanced slip ceased when the basal hydraulic system, expanded by cavity growth or ice

207 uplift, was able to reduce cavity overpressurization, thereby terminating jacking.

208 The seismic expression of these melt-driven events is complex and contains a long-period

209 tilt signal — not previously recognized in glacial settings — attributed here to hydraulic jacking.

210 While the process of hydraulic jacking has been modeled and inferred on hard-bedded glaciers

211 elsewhere from measurements of basal water pressure and ice surface velocity (e.g., Iken and

212 Bindschadler, 1986), the measurements presented here offer further observational evidence and

213 glaciological context for its identification in seismic and instrumental measurements. Future use

214 of broadband seismometers to record ground deformation in addition to elastic waves could

215 further illuminate hydrological controls on the dynamics of glaciers elsewhere.

216 Our subglacial observations further illustrate how, in circumstances like those observed at

217 Engabreen, temporary enhancement of basal sliding and ice-bed separation can become self-

218 arresting when the consequent changes to cavity volume and connectivity allow the excess water

219 to establish a more efficient passage through the system. While the tendency for sliding speed to

220 respond to meltwater input depends strongly on the rate of meltwater supply (e.g., Bartholomew

221 et al., 2012), the ability of a glacier to arrest meltwater-driven slip once initiated must be a

222 complex function of continued meltwater supply and bed geometry as well as antecedent

223 hydrological conditions. If bed geometry and roughness represents a common control on

224 termination of enhanced slip episodes across glacial systems, investigation of bed geometry

225 could allow assessment of the relative susceptibility of different glaciers to prolonged rapid

226 sliding.

227 ACKNOWLEDGMENTS

Page 10 of 15 
Publisher: GSA

Journal: GEOL: Geology

Article ID: G34760

228 We thank B. Peterson, P. Burkett, M. Lampert, H. Elverhoy, L. Zoet, R. Engeset, and H.

229 Benediktsson for assistance in the field. This work was supported by the U.S. National Science

230 Foundation (OPP-ARC-0909048, OPP-ARC-0907178, and OPP-ANT-0424589).

231 REFERENCES CITED

232 Anandakrishnan, S., and Bentley, C.R., 1993, Micro-earthquakes beneath Ice Streams B and C,

233 West Antarctica: Observations and implications: Journal of Glaciology, v. 39, no. 133,

234 p. $455-462$.

235 Bartholomew, I., Nienow, P., Sole, A., Mair, D., Cowton, T., and King, M.A., 2012, Short-term

236 variability in Greenland Ice Sheet motion forced by time-varying meltwater drainage:

237 Implications for the relationship between subglacial drainage system behavior and ice

238 velocity: Journal of Geophysical Research, v. 117, F03002, doi:10.1029/2011JF002220.

239 Cohen, D., Iverson, N.R., Hooyer, T.S., Fischer, U.H., Jackson, M., and Moore, P.L., 2005,

240 Debris-bed friction of hard-bedded glaciers: Journal of Geophysical Research, v. 110, no.

$241 \quad$ F2, p. 1-15, doi:10.1029/2004JF000228.

242 Cohen, D., Hooyer, T.S., Iverson, N.R., Thomason, J.F., and Jackson, M., 2006, Role of transient

243 water pressure in quarrying: A subglacial experiment using acoustic emissions: Journal of

244 Geophysical Research, v. 111, F03006, doi:10.1029/2005JF000439.

245 Genco, R., and Ripepe, M., 2010, Inflation-deflation cycles revealed by tilt and seismic records

246 at Stromboli volcano: Geophysical Research Letters, v. 37, no. 12,

247 doi:10.1029/2010GL042925.

248 Harper, J.T., Humphrey, N.F., and Greenwood, M.C., 2002, Basal conditions and glacier motion

249 during the winter/spring tranistion, Worthington Glacier, Alaska, USA: Journal of

250 Glaciology, v. 48, no. 160, p. 42-50, doi:10.3189/172756502781831629. 
Publisher: GSA

Journal: GEOL: Geology

Article ID: G34760

251 Iken, A., and Bindschadler, R.A., 1986, Combined measurements of subglacial water pressure

252 and surface velocity of Findelengletscher, Switzerland: Conclusions about drainage system

253 and sliding mechanism: Journal of Glaciology, v. 32, no. 110, p. 101-119.

254 Iverson, N.R., Cohen, D., Hooyer, T.S., Fischer, U.H., Jackson, M., Moore, P.L., Lappegard, G.,

255 and Kohler, J., 2003, Effects of basal debris on glacier flow: Science, v. 301, p. 81-84,

256 doi:10.1126/science.1083086.

257 Lappegard, G., Kohler, J., Jackson, M., and Hagen, J.O., 2006, Characteristics of subglacial

258 drainage systems deduced from load-cell measurements: Journal of Glaciology, v. 52,

259 no. 176, p. 137-148, doi:10.3189/172756506781828908.

260 Lei, X., Masuda, K., Nishizawa, O., Jouniaux, L., Liu, L., Ma, W., Satoh, T., and Kusunose, K.,

2612004 , Detailed analysis of acoustic emission activity during catastrophic fracture of faults in

262 rock: Journal of Structural Geology, v. 26, no. 2, p. 247-258, doi:10.1016/S0191-

263 8141(03)00095-6.

264 Mikesell, T.D., Van Wijk, K., Haney, M.M., Bradford, J.H., Marshall, H.-P., and Harper, J.,

265 2012, Monitoring glacier surface seismicity through time and space using Rayleigh waves:

266 Journal of Geophysical Research, v. 117, p. 1-12, doi:10.1029/2011JF002259.

267 Murray, T., and Clarke, G.K.C., 1995, Black-box modeling of the subglacial water system:

268 Journal of Geophysical Research, v. 100, no. B6, p. 10231-10245, doi:10.1029/95JB00671.

269 Roux, P.-F., Marsan, D., Metaxian, J.-P., O’Brien, G., and Moreau, L., 2008, Microseismic

270 activity within a serac zone in an alpine glacier (Glacier d'Argentiere, Mont Blanc, France):

271 Journal of Glaciology, v. 54, no. 184, p. 157-168, doi:10.3189/002214308784409053. 
Publisher: GSA

Journal: GEOL: Geology

Article ID: G34760

272 Shepherd, A., Hubbard, A., Nienow, P., King, M., McMillan, M., and Joughin, I., 2009,

273 Greenland ice sheet motion coupled with daily melting in late summer: Geophysical

274 Research Letters, v. 36, no. 1, L01501, doi:10.1029/2008GL035758.

275 Tsai, V.C., Rice, J.R., and Fahnestock, M., 2008, Possible mechanisms for glacial earthquakes:

276 Journal of Geophysical Research, v. 113, no. F3, p. 1-17, doi:10.1029/2007JF000944.

277 Walter, F., Clinton, J.F., Deichmann, N., Dreger, D.S., Minson, S.E., and Funk, M., 2009,

278 Moment Tensor Inversions of Icequakes on Gornergletscher, Switzerland: Bulletin of the

279 Seismological Society of America, v. 99, no. 2A, p. 852-870, doi:10.1785/0120080110.

280 Walter, F., Dreger, D.S., Clinton, J.F., Deichmann, M., amd Funk, M., 2010, Evidence for near-

281 horizontal tensile faulting at the base of Gornergletscher, a Swiss Alpine Glacier: Bulletin of

282 the Seismological Society of America, v. 100, no. 2, p. 458-472, doi:10.1785/0120090083.

283 Wiens, D., Pozgay, S., Shore, P., Sauter, A., and White, R., 2005, Tilt recorded by a portable

284 broadband seismograph: The 2003 eruption of Anatahan Volcano, Mariana Islands:

285 Geophysical Research Letters, v. 32, no. 18, L18305, doi:10.1029/2005GL023369.

286 Wiens, D.A., Anandakrishnan, S., Winberry, J.P., and King, M.A., 2008, Simultaneous

287 teleseismic and geodetic observations of the stick-slip motion of an Antarctic ice stream:

288 Nature, v. 453, no. 7196, p. 770-774, doi:10.1038/nature06990.

289 Winberry, J.P., Anandakrishnan, S., and Alley, R.B., 2009, Seismic observations of transient

290 subglacial water-flow beneath MacAyeal Ice Stream, West Antarctica: Geophysical

291 Research Letters, v. 36, no. 11, p. 1-5, doi:10.1029/2009GL037730.

292 Zoet, L.K., Anandakrishnan, S., Alley, R.B., Nyblade, A.A., and Wiens, D.A., 2012, Motion of

293 an Antarctic glacier by repeated tidally modulated earthquakes: Nature Geoscience, v. 5,

294 no. 9, p. 623-626, doi:10.1038/ngeo1555. 
Publisher: GSA

Journal: GEOL: Geology

Article ID: G34760

295

296

297

298

299

300

301

302

303

304

305

306

307

308

309

310

311

312

313

314 (see location in Fig. DR1B). Gray bars indicate the number of discrete events per 10 min window

315 detected by STA/LTA triggering in a 5-40 Hz passband (right axis). Black and purple lines are

316 the vertical and east-west components of tilt derived from ultra-long period seismic

317 measurements at station VS. 
Publisher: GSA

Journal: GEOL: Geology

Article ID: G34760

$318{ }^{1}$ GSA Data Repository item 2013xxx, xxxxxxxx, is available online at

319 www.geosociety.org/pubs/ft2013.htm, or on request from editing@geosociety.org or Documents

320 Secretary, GSA, P.O. Box 9140, Boulder, CO 80301, USA. 



\section{DATA REPOSITORY}

For Moore et al., 2013, Glacier slip and seismicity induced by surface melt

\section{FIELD SETTING}

Tunnels in the crystalline bedrock beneath Engabreen were excavated in the 1980s and 1990s as part of a hydropower project, administered and maintained by a partnership between the national energy company, Statkraft, and the Norwegian Water Resources and Energy Directorate (NVE). The tunnel system intersects the glacier bed at several locations ("intakes", Figs. DR1 and DR2) where basal meltwater is captured and routed to a hydroelectric power generating facility. Additional surface water intakes in an adjacent valley contribute subaerial snow and ice melt during the melt season through Fonndalstunnelen ("F" in Fig. 1 and Fig. DR1A). One tunnel that intersects the glacier bed has been reserved for subglacial research and allows two points of direct access to the bed for deployment of instrumentation (the "research tunnel" in Fig. DR1B). One access point is through a concrete and steel-reinforced "horizontal shaft" (Fig. DR1B and DR2A). The second access is a "vertical shaft" through $3 \mathrm{~m}$ of rock in the ceiling of the tunnel. A concrete footing and heavy steel support structure within the vertical shaft allow instrumentation to be installed flush with ice sliding across an area of relatively smooth bedrock (Fig. DR1B and DR2). When not in use, both access points are barricaded with customized steel barriers. Water pumps and a water heater supply hot water from a subglacial laboratory approximately $70 \mathrm{~m}$ away from the access shafts (Fig. DR1B). Hot water is pumped through insulated hoses to the research tunnel, allowing temporary workspace to be melted at the base of the glacier.

Discharge of subglacial water through this tunnel system is continuously monitored by NVE and Statkraft using several automated stations positioned at different points in the tunnels. Water stage is monitored using OTT Orpheus Mini pressure transducers and converted to discharge with local rating curves. Changes in the discharge from the subglacial intake tunnels may be assumed to reflect the supply-induced changes in the hydraulic capacity of the subglacial drainage system.

Ice overlying the research tunnel is approximately $200 \mathrm{~m}$ thick, heavily crevassed, and has a surface slope of approximately $10^{\circ}$ (Iverson et al., 2007). The glacier surface elevation there is approximately $830 \mathrm{~m}$ above sea level (Lappegard et al., 2006). Surface velocity in this area is $\sim 0.2 \mathrm{~m} /$ day (Jackson et al., 2005) and measured sliding velocities during spring are typically $\sim 0.1 \mathrm{~m} /$ day (Cohen et al., 2005; Iverson et al., 2007). The intensely-foliated metamorphic rocks over which Engabreen slides exhibit local relief in places exceeding $1 \mathrm{~m}$ due to differential weathering and erosion along foliation and joint trends. The resulting glacier bed has a high and spatially-variable roughness.

\section{MATERIALS AND METHODS}

From March 13, 2010, to June 8, 2011, numerous instruments were deployed the base of the glacier in and around the vertical shaft to measure basal water pressure, bed normal stress, basal shear stress, sliding displacement, ice acceleration, seismicity and acoustic emissions (Fig. DR2B-C). Many of these instruments were extracted, tested and either re-deployed or replaced in early May 2011. Mechanical measurements at the bed were recorded from March 18 to June 11, 2010 and from May 8 to June 8, 2011. A cavity was melted at the bed for instrument deployment from March 7-11, 2010 (through the vertical shaft) and from May 2-8, 2011 (through the horizontal shaft). Instrumental measurements indicate that creep of ice closes these cavities within two to three days.

\subsection{Friction panel}

The friction panel has been described elsewhere (Cohen et al., 2005; Iverson et al., 2003); we review only key aspects of it here and refer the reader to this prior work for details. The panel consisted of a $0.3 \mathrm{~m}$ diameter granite tablet embedded in a stainless steel housing that sat atop seven low-friction thrust bearings, all housed within a steel and delrin plastic frame that positioned the panel surface flush with the glacier bed (Fig. DR2B-C). The low-friction bearings allowed nearly all of the the shear force exerted by the glacier base over the granite tablet to be transferred to two horizontally-mounted load cells (Geokon 4900X) that presssed against the side of the granite tablet's housing. The force on these load cells was converted to shear stress by taking the square root of the sum of the squared horizontal forces and dividing by the surface area of the tablet. In 2010, only one of the two shear load cells was functional, so the 
reported shear stress in 2010 represents a minimum value. Similar load cells were mounted vertically in two places adjacent to the granite tablet to measure normal force on the bed.

The basal normal stress was originally computed from these measurements by assuming that these vertical load cells measured the effective normal stress plus the water pressure in the thin water film separating the ice from bedrock. However, observations and measurements (discussed in the main text) consistent with a thin layer of unfrozen sediment at the interface indicate that the measured load must have been partitioned between the stress transferred through the thin water film and any particles within the footprint of the load cell cover that supported some of the ice overburden stress. If the surface of the load-cell cover (surface area $A_{\text {tot }}$ ) is in real contact with particles over an area $s A_{\text {tot }}$ and those particles transfer the local effective stress to the load cell, the actual normal stress is $\sigma_{n}=\sigma_{m e a s}+s p_{w}$. The value of $s$ varies in time and space and can be constrained only to lie between zero and the volume fraction of particles $(1-n)$, where $n$ is the porosity of the sediment layer. The values reported for effective stress in the main text are computed by assuming $s=0.3$. Two water pressure transducers (Geokon 4500S) attached to the base of the granite tablet measured the fluid pressure independently in water-filled canisters that were connected with basal water through $10 \mathrm{~mm}$ diameter porous discs embedded in the granite.

Lappegard and Kohler (2005) investigated the basal hydraulic system in the area of the research tunnel by pumping water through boreholes (see Fig. DR2B) to the glacier bed and measuring the timing and magnitude of changes in water pressure in boreholes and load cells elsewhere on the glacier bed. Among the key results of this work were the identification of seasonally-varying efficiency and connectedness in the basal hydraulic system. During winter and early spring, expansion of the experimental pressure disturbance over the relatively-flat region of the bed surrounding the vertical shaft was slow and incomplete (see their Figs. 3 and 4). This has been interpreted to indicate that the vertical shaft area is typically unconnected or poorly connected to the winter hydraulic system except when water pressure is elevated and sustained over a sufficiently large area of the bed to locally lift the glacier.

\subsection{Other basal measurements}

Basal sliding displacement was measured with extensometers (Unimeasure HX-PA series) attached to vinyl-covered (2010) or kevlar-sheathed (2011) cables. These cables passed through boreholes or through conduits in the panel frame and were connected to steel or ABS plastic anchors within the basal ice. Four of these extensometer/anchor devices were deployed in 2010 and five in 2011. In most cases, connections to the anchors were lost within 1 day to 5 weeks of deployment. Since deployment in 2010 was in March, none of the anchors yielded clear sliding signals by mid-May. In 2011, only one extensometer recorded displacement after installation, suggesting that the remaining four cables or cable-anchor connections were compromised quickly.

Data from the panel instruments were recorded with Campbell CR10X and CR1000 dataloggers equipped with a Campbell multiplexer and a vibrating wire interface (AVW1) and automatically downloaded to a laptop running Loggernet software. Timestamps were acquired from the dataloggers, which were synchronized periodically with the laptop. During late March 2010 and late May 2011, a sledgehammer equipped with a trigger switch wired to the CR1000 was pounded on the tunnel floor to allow later synchronization between the seismic data recorders and the dataloggers.

In both 2010 and 2011, an acoustic emissions (AE) sensor (Physical Acoustics R151-AST, $150 \mathrm{KHz}$ resonant frequency) was bonded to the base of the upper platen of the panel housing and logged with a dedicated computer system (Physical Acoustics SAMOS system with AEWin software) powered by a wall outlet in the research tunnel. Owing to the relatively long duration of the measurements and high acoustic data acquisition rates, information from discrete emissions only exceeding $40 \mathrm{~dB}$ amplitude was recorded and saved, and no waveforms were recorded. The AE system and its components are described further in an earlier paper (Cohen et al., 2006). The sensor deployed in 2010 failed during or shortly after installation, so data are reported only from 2011.

Custom wireless "smart rocks" designed at lowa State University were installed in both 2010 and 2011 in basal ice within 1.5 meters of the glacier bed. Each smart rock consisted of a low-noise triaxial accelerometer (Bosch Sensortec BMA-180 $1 \mathrm{~g})$ connected to a microcontroller (Arduino Pro Mini 328) equipped with a low-power XBee wireless radio transmitter. The electronics were powered by lithium batteries and housed within capped, double-walled PVC cylinders. Each finished smart rock was approximately $25 \mathrm{~cm}$ long and $10 \mathrm{~cm}$ in diameter. Data were transmitted at $\sim 90 \mathrm{~Hz}$ through the 
bed to an XBee gateway receiver (Digi International) equipped with a high-gain dipole antenna. This antenna was connected directly to a PC laptop running a terminal capture program.

The smart-rocks were expected to record any abrupt changes in local basal sliding velocity associated with stick-slip and concomitant seismicity. As shown in Fig. DR5A, no distinct acceleration signals stand out from the accelerometer noise, even during the May 11 event. This finding is consistent with the interpretation that the discrete seismic events recorded by the broadband seismometers were unrelated to nearby basal slip. The accelerometer did, however, record a DC signal indicative of the orientation of its axes relative to the gravitational acceleration. Thus, a low-pass-filtered signal from the accelerometer can be viewed as a tiltmeter record, providing some insight into changes in strain regime in the ice surrounding the accelerometer (Fig. DR5B). During the May 11 event, the accelerometer recorded the temporary suspension of an otherwise steady and slow rotation. This change in rotation rate may be interpreted to represent a tilt signal counterbalancing steady rotation or the passage of strain transients longitudinally through the glacier.

\subsection{Seismic measurements}

Guralp 3-T broadband seismometers and Reftek RT130 data loggers were installed throughout subglacial tunnel system, including three locations in the research tunnel shown in Fig. DR1B (VS, HS, 001). Each station recorded continuously at $500 \mathrm{~Hz}$ during the spring of 2010 and 2011. The seismometers were installed directly on the rock floor of the tunnel (001) or on concrete slabs adjacent to the basal access points (HS and VS) and were individually powered with lead-acid batteries. Data downloaded from the broadband seismic stations were inspected in raw form and after processing and filtering in the desired frequency bands. Data were converted from raw form to velocity using the instrument response functions appropriate for the Guralp 3T (see detailed instrument documentation on the IRIS PASSCAL website, http://www.passcal.nmt.edu/content/instrumentation/sensors/broadband-sensors/cmg-3t-bb-sensor). All data are now available from the IRIS seismic catalog listing (http://www.iris.edu/SeismiQuery/) for temporary network 3C.

Impulsive events in the $5-40 \mathrm{~Hz}$ frequency band were identified with an automated phase-picking algorithm and binned as a function of time. Due to an increase in seismic noise associated with increased discharge in subglacial tunnels (described further below), the threshold for observing an event is higher later in the spring time-series. The increased noise limited detection of smaller events, however hundreds of events were still observed each day. A subset of the picked events was inspected for phase relationships, and in most cases the signals were dominated by retrograde particle motion (recognized by a $90^{\circ}$ phase lag between one or both horizontal channels and the vertical channel), consistent with Rayleigh waves (Fig. DR6). Indeed, preliminary locations for 50 of these events are in heavily-crevassed regions of the ice surface.

Ultra-long period (ULP) signals with period longer than 100 seconds were mostly eliminated with standard deconvolution procedures within the design frequency range of the instrument. Weilandt and Forbriger (1999) showed that at periods exceeding 50 seconds, similar broadband instruments recorded primarily ground tilt. Following these authors, Wiens and others (2005) and Genco and Ripepe (2010) verified that ultra-long period excursions recorded in broadband seismometers on volcanoes provided a high-fidelity measure of tilt. We followed these authors in extracting tilt from the ULP response of our broadband seismometers. Raw digital seismic records were initially filtered in a 10035,000 second passband. As noted by Wiens and others (2005), while this passband is outside the optimal range of the instrument, the instrument's sensitivity to acceleration falls off linearly with frequency making recovery of long period acceleration signals possible. Instrument response files obtained from the IRIS Data Management Center were used to recover the broadband response without additional frequency-domain filtering using SAC (Seismic Analysis Code, available from the PASSCAL instrument center). Corrected ground velocity data were then differentiated to acceleration, which in the sensor's horizontal channels is proportional to tilt (Genco and Ripepe, 2010). For small angles, an acceleration $a$ corresponds to a tilt of $a / \mathbf{g}$, where $\mathbf{g}$ is the gravitational acceleration vector. From the measurements at Engabreen, tilt angles did not exceed about $6 \mu \mathrm{rad}$ or $0.0003^{\circ}$ from the horizontal.

\section{SUPPORTING RESULTS}

\subsection{Ancillary observations from May 11, 2011}


During the May 11 meltwater event, the station at HS began to record high-amplitude broadband noise that made further detection of discrete seismic events at that station impossible. A much more subdued increase in noise was also noted in stations 001 and VS, $\sim 4 \mathrm{~m}$ and $\sim 6 \mathrm{~m}$ away from station HS, respectively. The onset of this noise during the meltwater event coincided with the cessation of enhanced basal sliding at $\sim 06: 30$ local time. Based on our direct observations of vigorous water flow through seams in the barricaded horizontal shaft door on May 18 and the seismic record from the same time, we infer that this noise was caused by disturbance and partial submergence of station HS by meltwater and entrained sand (Burtin et al., 2008). This correlation is consistent with an interpretation that hydraulic jacking enlarged basal hydraulic passages and allowed water in over-pressurized cavities to establish or escape into a more efficient drainage system, which in this case included the research tunnel.

Prior to the onset of slip, if effective stress at the debris-bed interface was sufficiently high prior to 04:00 on May 11, such a debris layer would have been immobile due to high friction, with basal motion accommodated by sliding of ice across the top of the debris layer. At the onset of meltwater pressurization, jacking in hydraulically-connected areas of the bed shifted shear stress to poorly-connected areas, thereby increasing shear stress on the debris layer. Uplift of the ice also reduced the local effective stress, so the frictional strength of the debris-rock interface at the base of the debris layer was reduced until shear stress was sufficient to induce slip there. The correlation between the end of the slip episode and the second peak in panel shear stress is consistent with termination of frictional slip and re-strengthening of the debris-rock interface during the recovery of water pressure and normal stress.

\subsection{Meltwater events of May 16, 2011 and May 15, 2010}

The most prominent seismic and hydraulic disturbance at the glacier base in spring 2011 was on the morning of May 11. As discussed in the main text, this event is interpreted to be the result of extensive surface snowmelt driving downward crevasse propagation and release of meltwater to the bed. A second prominent event occurred late in the evening of May $16^{\text {th }}$ and seems to have been triggered by rain rather than directly by snowmelt. The glacier response to these meltwater events was similarly expressed in seismic measurements from multiple broadband stations as well as by the friction panel (Fig. DR7). Whereas the focus in the main text was to present and interpret the events of May 11 when the dataset is richest and most complete, we provide data from the May 16 event here for comparison and to demonstrate that the May 11 event was not unique.

An additional event expressed similarly in the friction panel and seismic data was recorded on May 15 of 2010 (Fig. DR89). Similar to the May 11, 2011 event, this event occurred following several days of sustained warming and presumed surface melting. Instrumental coverage at this time, two months after deployment, was sparser than in 2011, but the sequence of events is consistent. Meltwater supply to the bed increased, causing disturbance of the basal hydraulic system measured as large amplitude swings in effective stress, shear stress and water pressure. An ultra-long period tiltlike signal marked the onset of this disturbance and were followed by sustained increase in the discharge from the subglacial intakes (Fig. DR8).

\subsection{Physical analysis of the ULP source}

Constraints on the ULP seismic source may be provided by estimating the deformation of the bed as a consequence of hydraulic jacking. Consider the idealized case of a hard, bumpy bed with lee cavities sustained with basal water pressure $p_{c}<p_{o}$, where $p_{o}$ is the ice overburden pressure. In the hours before the May 11 event, the basal water pressure was less than 1.6 MPa. Over the course of the event, water pressure at the panel increased to at least $1.8 \mathrm{MPa}$, approximately equal to $p_{o}$. Assuming that the magnitude of eventual pressure increase in the linked cavity system was at least as large as the pressure change in the unconnected system (i.e., near the panel), pressure in the linked cavity system must have risen at least $\Delta p_{c}=0.2 \mathrm{MPa}$. Assume that cavities cover an areal fraction of the bed $a_{c}$ of 0.1 to 0.5 (Walder and Hallet (1979) measured 0.2 for Blackfoot Glacier). The added pressure on the bed would be $\Delta p=\Delta p_{c} a_{c}$, averaged over an area of the bed containing many bumps and cavities. Within the assumed range of $a_{c}$, the total pressure change would be 0.02 to $0.1 \mathrm{MPa}$. For crystalline bedrock with a Young's modulus $E$ of $50 \mathrm{GPa}$ (Turcotte and Schubert, 2002), and assuming uniaxial strain due to a uniformly distributed surface load, deformation of a $h=5 \mathrm{~m}$ thick column of rock between the glacier bed and the tunnel floor would be $\Delta z=h \Delta p / E$, or as large as $0.01 \mathrm{~mm}$. Indeed, the presence of a void in the rock (i.e., the research tunnel) could locally enhance the deformation under the added water pressure load, leading to larger and more complex deformations than calculated by this simplistic analysis.

Page 4 of 15 
While we do not have sufficient information to undertake a rigorous analysis of the deformation of the subglacial rock, a tilt angle of $5 \mu \mathrm{rad}$ (e.g., Fig DR4, DR7-9) would accompany rigid rotation by $0.05 \mathrm{~mm}$ of a member of characteristic length of $l=10 \mathrm{~m}$, which is a small but reasonable length scale for a water pressure disturbance and is approximately the length of the shaft area of the research tunnel (Fig. DR1B).

\section{References}

Burtin, A., Bollinger, L., Vergne, J., Cattin, R., and Nábělek, J.L., 2008, Spectral analysis of seismic noise induced by rivers: A new tool to monitor spatiotemporal changes in stream hydrodynamics: Journal of Geophysical Research, v. 113, no. B5, p. 1-14, doi: 10.1029/2007JB005034.

Cohen, D., Hooyer, T.S., Iverson, N.R., Thomason, J.F., and Jackson, M., 2006, Role of transient water pressure in quarrying: A subglacial experiment using acoustic emissions: Journal of Geophysical Research, v. 111, no. F3, p. F03006, doi: 10.1029/2005JF000439.

Cohen, D., Iverson, N.R., Hooyer, T.S., Fischer, U.H., Jackson, M., and Moore, P.L., 2005, Debris-bed friction of hardbedded glaciers: Journal of Geophysical Research, v. 110, no. F2, p. 1-15, doi: 10.1029/2004JF000228.

Genco, R., and Ripepe, M., 2010, Inflation-deflation cycles revealed by tilt and seismic records at Stromboli volcano: Geophysical Research Letters, v. 37, no. 12, doi: 10.1029/2010GL042925.

Iverson, N.R., Cohen, D., Hooyer, T.S., Fischer, U.H., Jackson, M., Moore, P.L., Lappegard, G., and Kohler, J., 2003, Effects of basal debris on glacier flow.: Science (New York, N.Y.), v. 301, no. 5629, p. 81-4, doi: 10.1126/science.1083086.

Iverson, N.R., Hooyer, T.S., Fischer, U.H., Cohen, D., Moore, P.L., Jackson, M., Lappegard, G., and Kohler, J., 2007, Softbed experiments beneath Engabreen, Norway: regelation infiltration, basal slip and bed deformation: Journal of Glaciology, v. 53, no. 182, p. 323-340, doi: 10.3189/002214307783258431.

Jackson, M., Brown, I.A., and Elvehøy, H., 2005, Velocity measurements on Engabreen, Norway: Annals of Glaciology, v. 42 , no. 1, p. 29-34.

Lappegard, G., and Kohler, J., 2005, Determination of basal hydraulic systems based on subglacial high-pressure pump experiments: Annals of Glaciology, v. 40, no. 1, p. 37-42, doi: 10.3189/172756405781813681.

Lappegard, G., Kohler, J., Jackson, M., and Hagen, J.O., 2006, Characteristics of subglacial drainage systems deduced from load-cell measurements: Journal of Glaciology, v. 52, no. 176, p. 137-148, doi: 10.3189/172756506781828908.

Turcotte, D., and Schubert, G., 2002, Geodynamics:.

Walder, J., and Hallet, B., 1979, Geometry of former subglacial water channels and cavities: Journal of Glaciology, v. 23, no. 89, p. 335-346.

Wielandt, E., and Forbriger, T., 1999, Near-field seismic displacement and tilt associated with the explosive activity of Stromboli: Annali di Geofisica, v. 42, no. 3, p. 407-416.

Wiens, D., Pozgay, S., Shore, P., Sauter, A., and White, R., 2005, Tilt recorded by a portable broadband seismograph: The 2003 eruption of Anatahan Volcano, Mariana Islands: Geophysical Research Letters, v. 32, no. 18, p. L18305, doi: 10.1029/2005GL023369. 
Page 6 of 15 


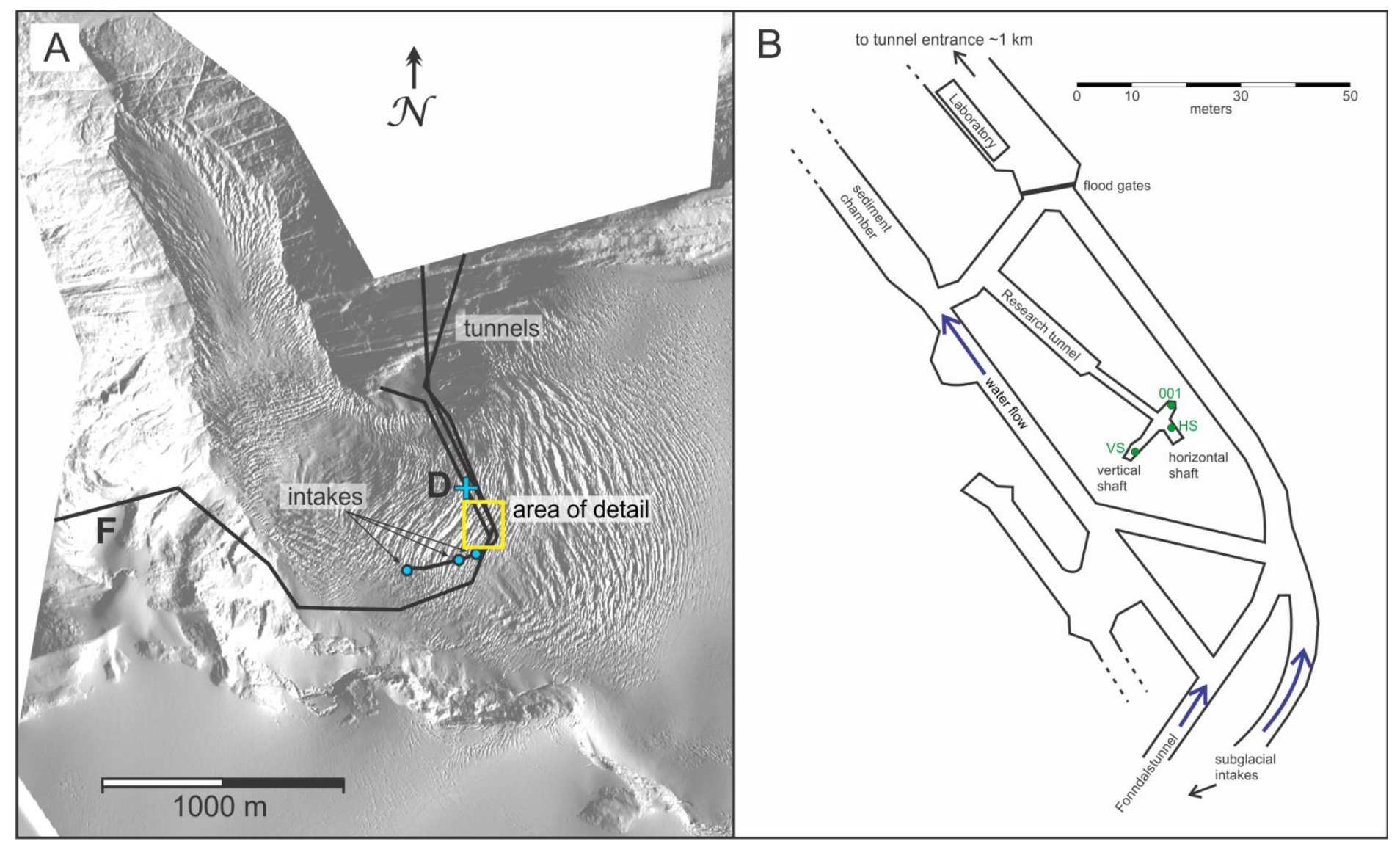

FIG DR1. Maps of the Engabreen subglacial tunnel system. A. Schematic layout of the tunnel system superimposed on a shaded relief map derived from airborne laser altimetry (as in Fig. 1). The tunnel marked F denotes Fonndalstunnelen, which captures subaerial snow and ice melt in a valley west of Engabreen. Three blue circles marked "intakes" capture water draining along the glacier bed. The blue cross marked "D" indicates the approximate location of the gaging station at the downstream end of the sediment chamber. An additional gaging station measures flow above the junction of Fonndalstunnelen with the tunnel draining the subglacial intakes. The yellow box shows the area detailed in panel B. B. Schematic tunnel layout in the area of the subglacial research tunnel and the subglacial laboratory. Access to the glacier bed is through the horizontal and vertical shafts in the southeast end of the research tunnel. Green circles near the shafts denote the locations of broadband seismometers installed during 2010 and 2011. 
A

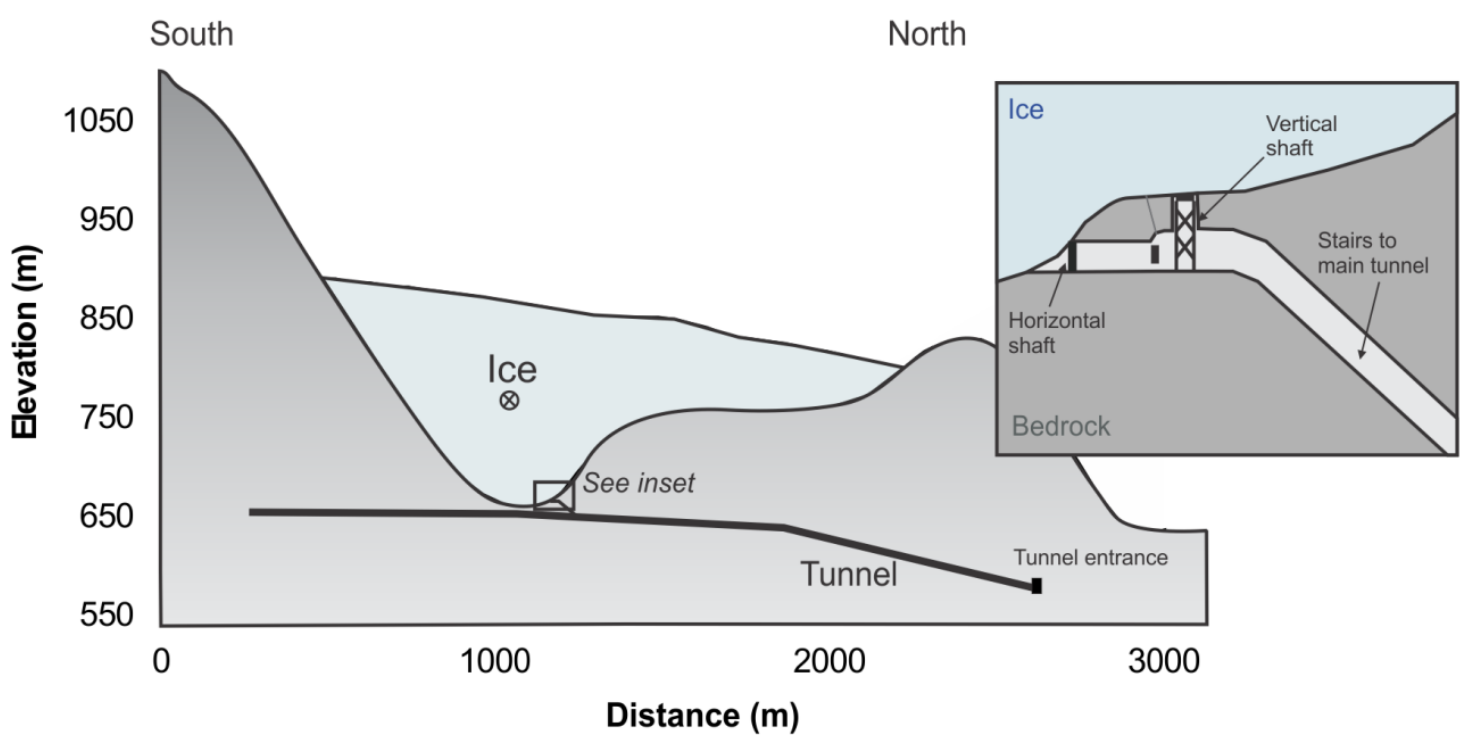

B

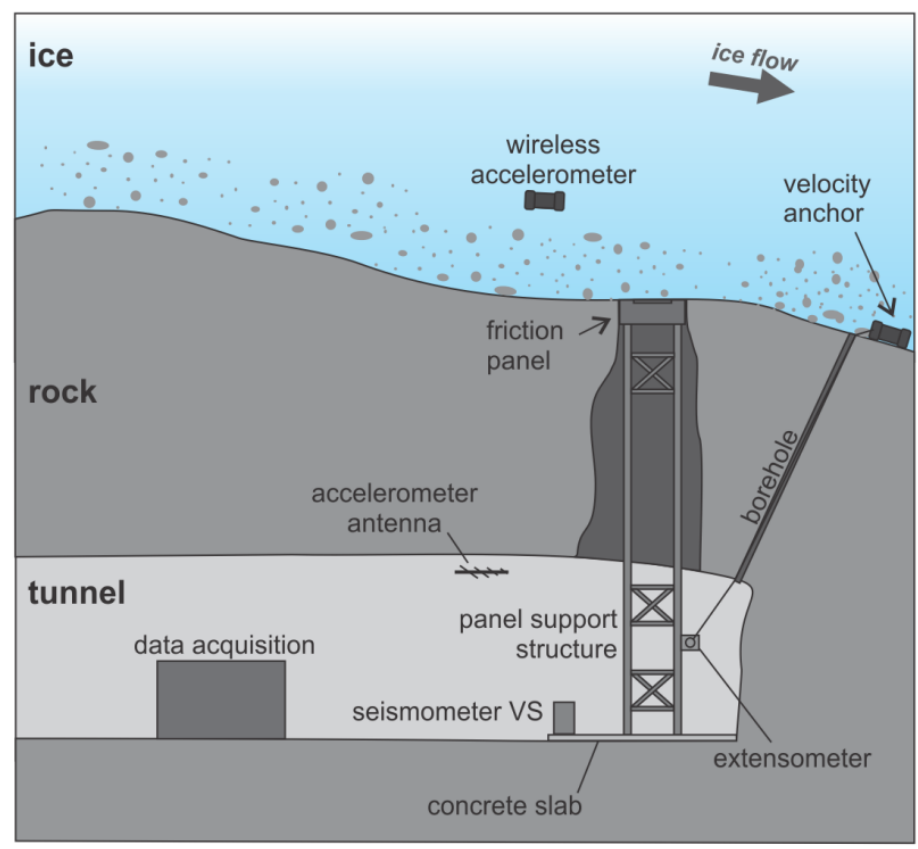

C

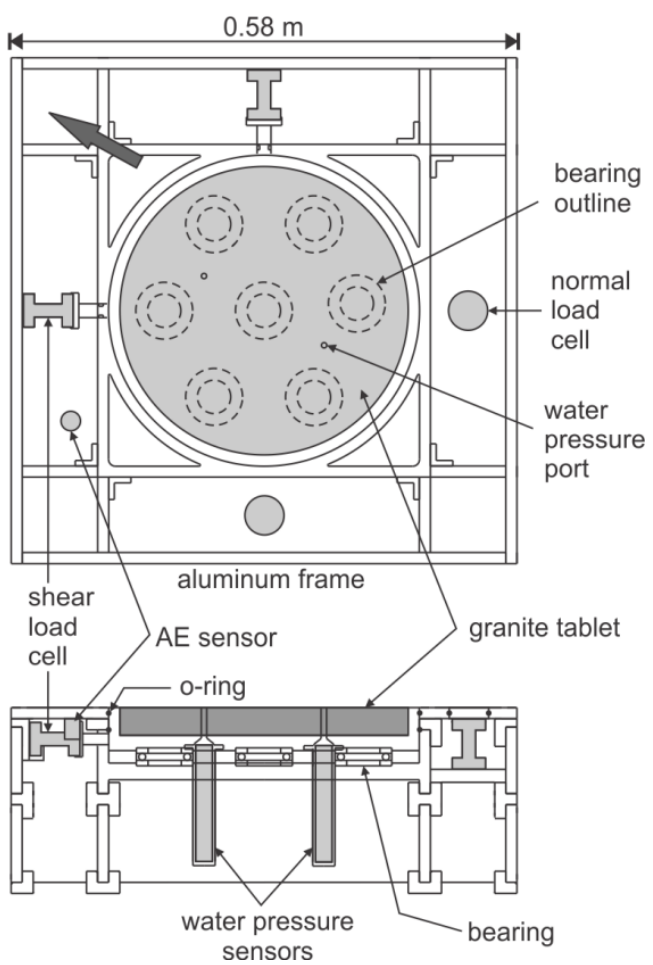

Fig. DR2. Schematic diagrams of the subglacial access points and research instrumentation used in the vertical shaft area. A. Schematic north-south cross-section across Engabreen in the vicinity of the subglacial accesses. Inset shows an enlargement of the upper part of the research tunnel (floor-to ceiling tunnel height is approximately $3 \mathrm{~m}$ ) B. Schematic layout of subglacial instrumentation near the vertical shaft. See supplementary text for descriptions of each instrument. Floor-to-ceiling height of the tunnel is approximately $3 \mathrm{~m}$. C. Dimensional drawings showing the key components of the friction panel. The upper drawing is a map-view and the lower drawing is a cross-section parallel to an edge of the panel but oblique to ice flow. Components described in the supplementary text are shown in gray. The dark gray arrow in the upper left indicates the local ice flow direction as inferred from striations in the bedrock. 

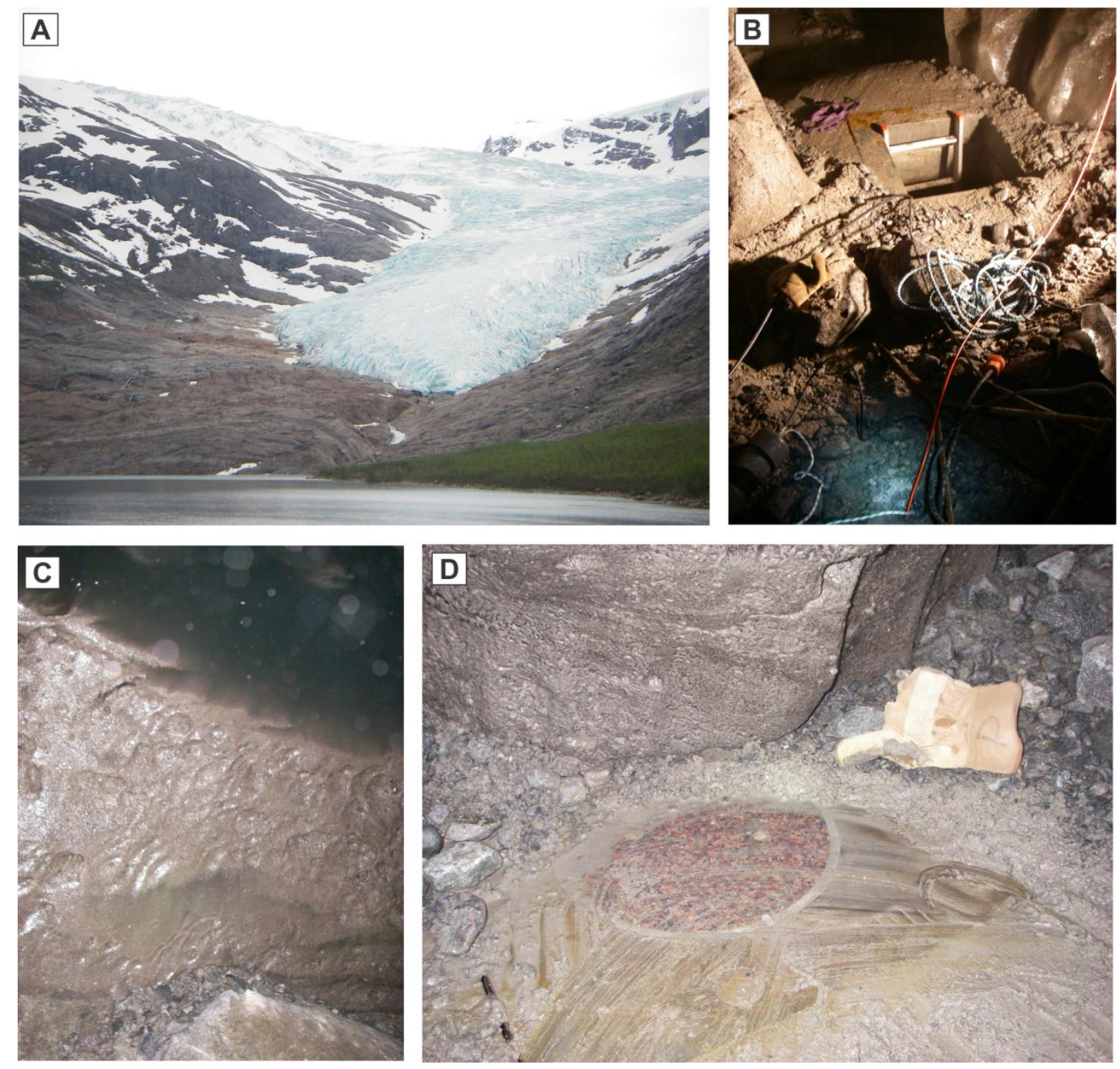

Fig. DR3. Photos of Engabreen and the the ice-bed interface. A. Engabreen's terminus from the north taken in May 2011. B. The vertical shaft opening $(0.58 \mathrm{~m}$ across) from above, taken from inside a cavity melted into basal ice. A gray smartrock enclosure is shown in the lower left corner. Striations on the bedrock in the upper part of the photo indicate the local ice-flow direction into the page. C. Close-up of debris-bearing basal ice (brown band in the center) beneath clear ice and resting on bedrock (the light brown area visible in the lower middle and lower right of the photo). A thin, unfrozen gravelly sediment layer appears to separate the dirty basal ice from the rock beneath in some places. The field of view is approximately $0.5 \mathrm{~m}$ from top to bottom. D. Ice encroaching on the friction panel 24 hours after installation. The $0.3 \mathrm{~m}$ diameter pink granite tablet is $\sim 30 \%$ covered with basal ice and gravelly sand that was melted out of the ice. The finger on the glove is pointing in the flow direction. Photo taken on May 6, 2011. 

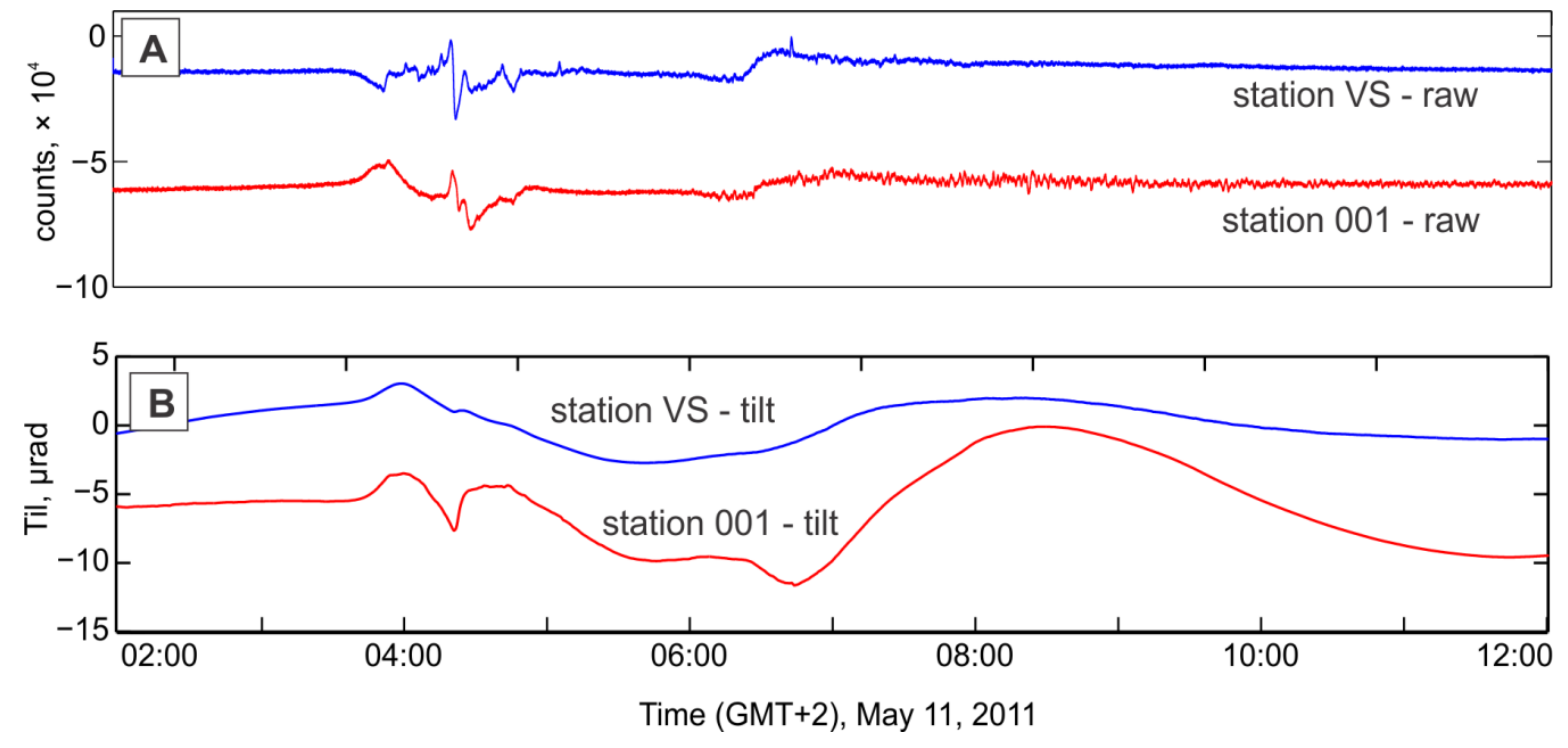

Fig. DR4. Comparison of the May 11, 2011 meltwater event as measured in two broadband seismometers located on opposite ends of the access area in the research tunnel. A. Raw E-W component of seismicity for stations VS ad 001 in the research tunnel, low-pass filtered below $1 \mathrm{~Hz}$ and expressed in digital counts. See Fig. DR1 for seismometer locations. B. ULP seismometer-derived tilt angle, from the same components of the broadband seismometers shown in A, band-pass filtered from 100-35,000 seconds. 


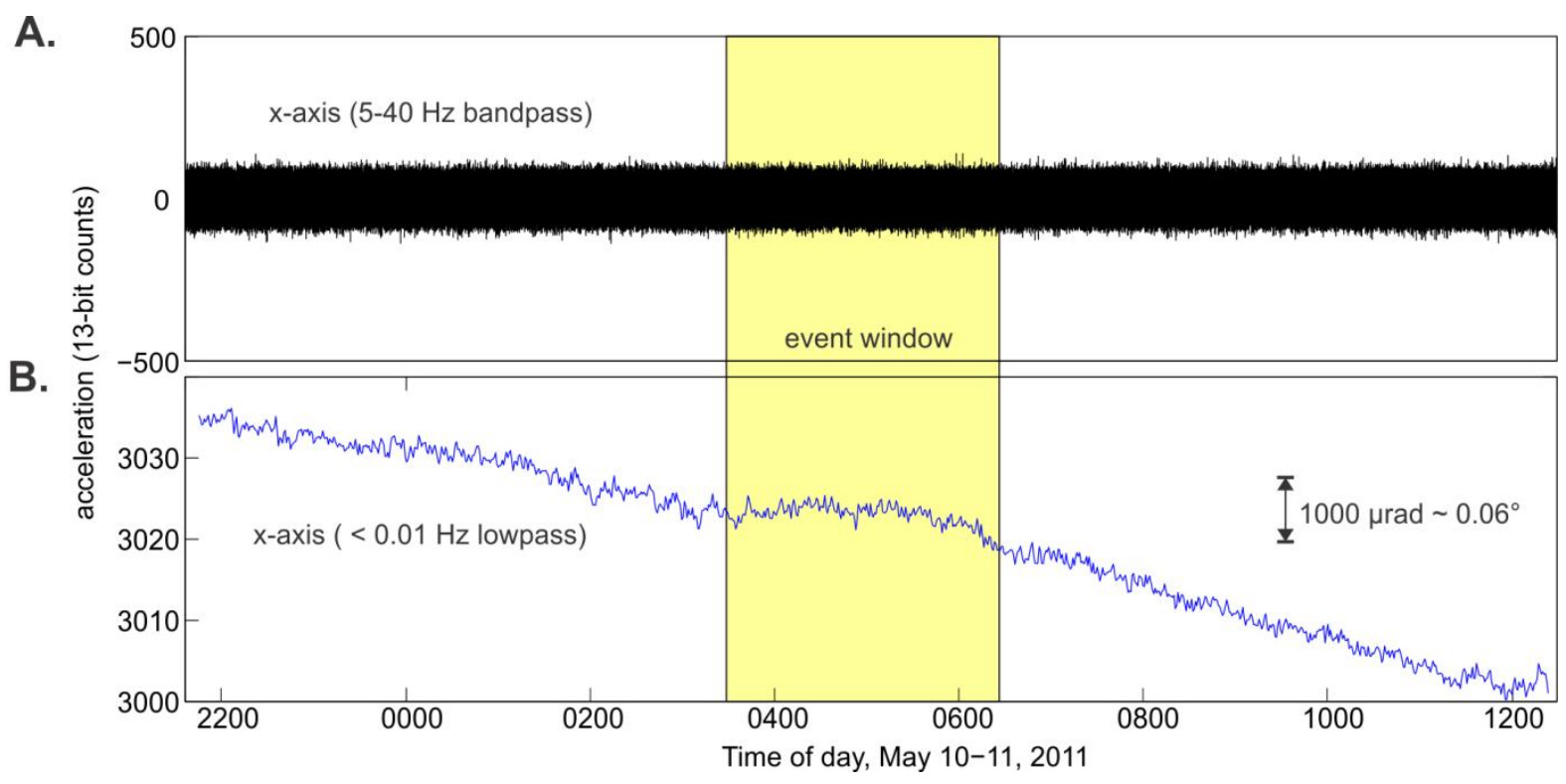

Fig. DR5. Wireless accelerometer data from a single axis of a "smart rock" embedded in the basal ice, $1.0 \mathrm{~m}$ above the glacier bed near the friction panel, during late night May 10 and the morning of May 11, 2011. A. Bandpass-filtered (5-40 $\mathrm{Hz}$, 5-pole Butterworth) $\mathrm{x}$-axis acceleration. B. Low-pass filtered $(<0.01 \mathrm{~Hz})$ data from the same axis showing interruption of a transient bias shift during the same time that other subglacial measurements (shown in Fig. 3 in the main text) indicate disturbances in stress, water pressure and the character of sliding (indicated by the yellow box labeled "event window"). At the time of installation in the basal ice, the x-axis was oriented approximately NW-SE. 

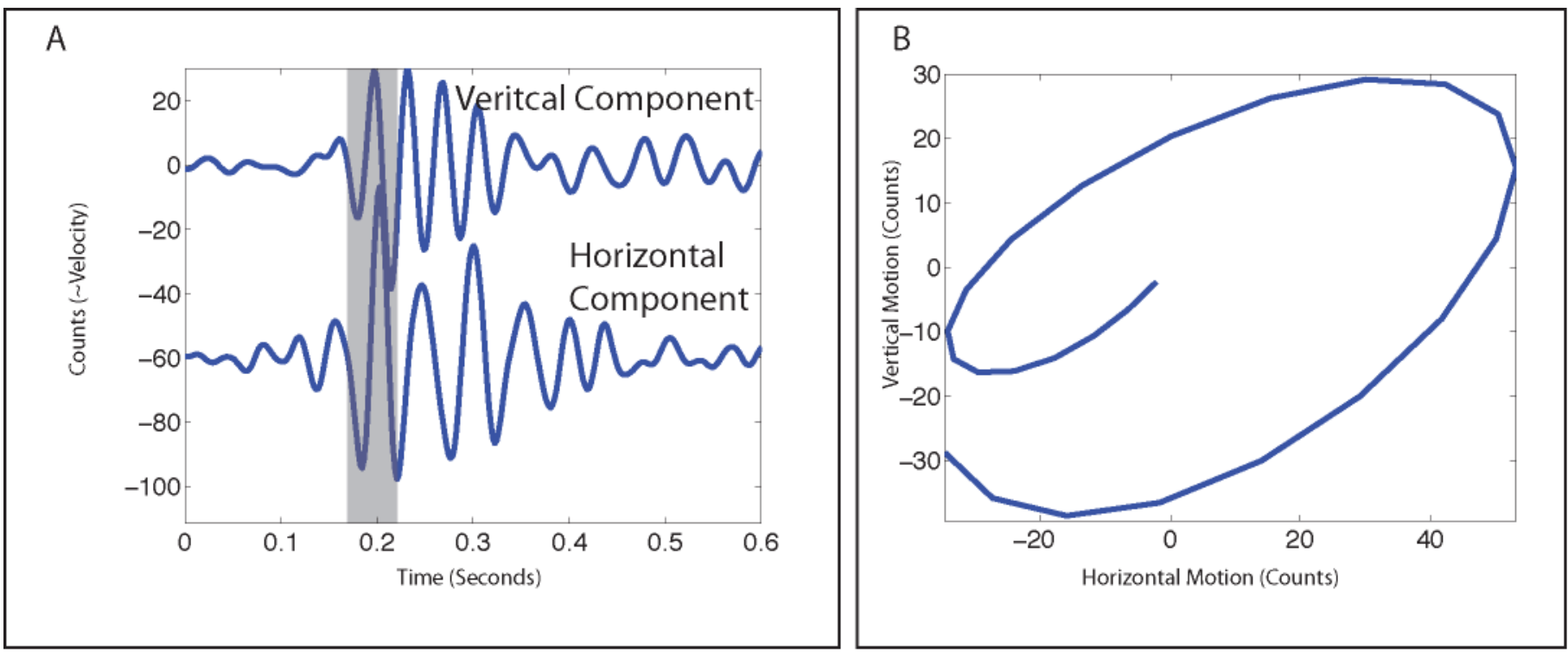

Fig. DR6. Example icequake recorded by seismometer 001 in the research shaft. A. Vertical and horizontal components of motion for a typical icequake with a $5-30 \mathrm{~Hz}$ bandpass filter applied. B. Particle motion plot for shaded region in A, showing retrograde motion typical of Rayleigh waves and indicating shallow origin. 

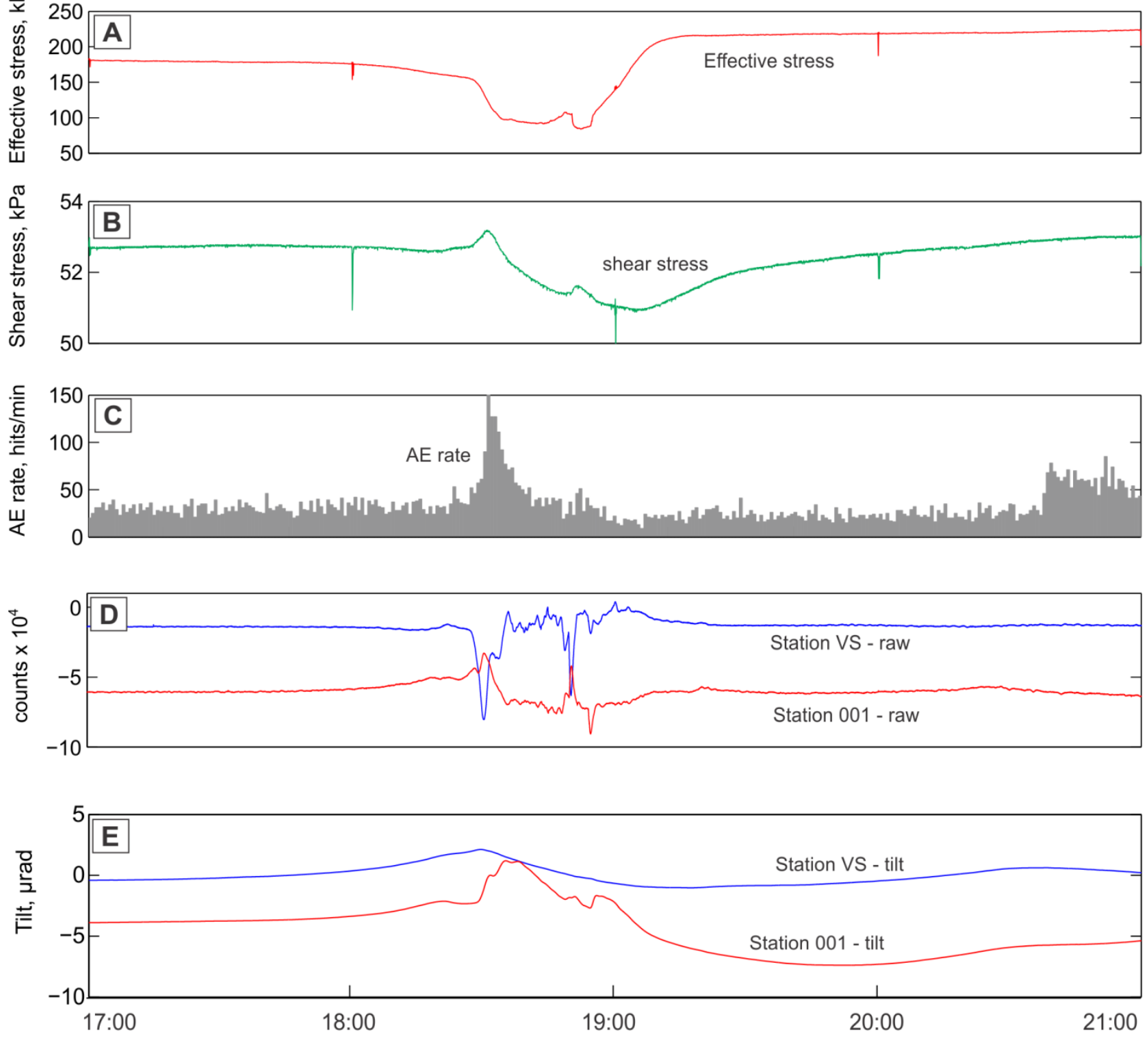

Time (GMT+2), May 16, 2011

Fig. DR7. Meltwater event of May 16, 2011 as recorded in the friction panel and broadband seismometers. A. Basal effective stress on the panel; B. Shear stress on the panel. C. Acoustic emissions rate from the friction panel. D. Raw E-W component of seismicity for stations VS and 001 in the research tunnel, low-pass filtered below $1 \mathrm{~Hz}$ and expressed in digital counts. See Fig. DR1 for seismometer locations. E. ULP seismometer-derived tilt angle from the same components of the broadband seismometers shown in D, band-pass filtered from 100-35,000 s. 


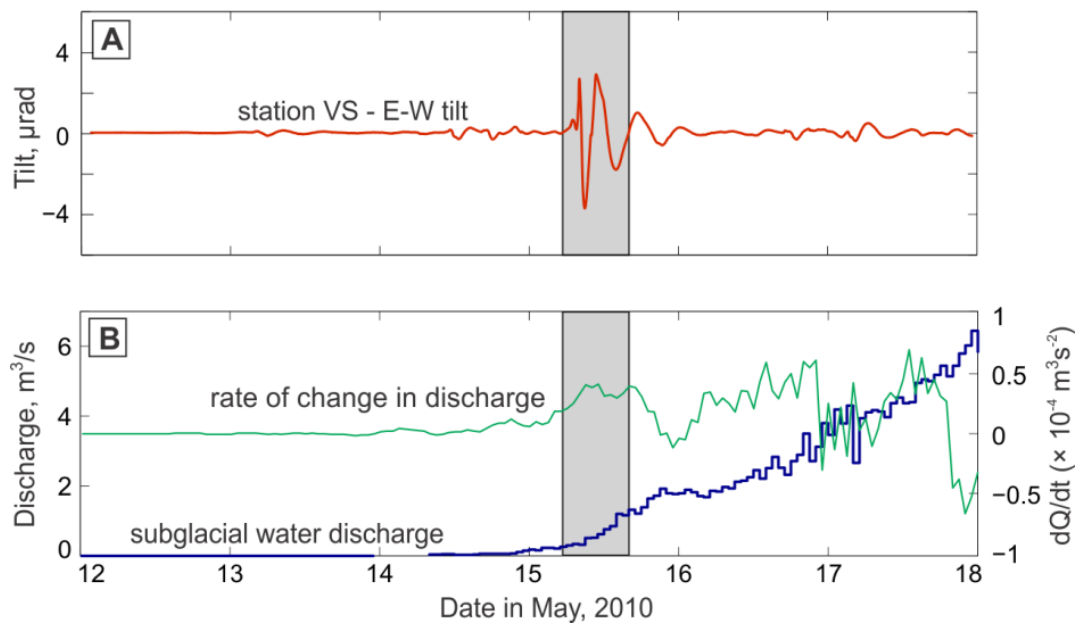

Fig. DR8. Long-period tilt and subglacial discharge from May 12-18, 2010. The gray shading encloses the May 15 event discussed in the text and shown in Fig. DR9. A. Tilt magnitude derived from long-period seismic record in the E-W component of broadband seismometer at station VS. B. Subglacial component of water discharge through the collection tunnels (blue) and its time derivative (green). The time derivative was computed numerically by forward differencing after applying a 5-point ( 2 hour) moving average filter the discharge data. 

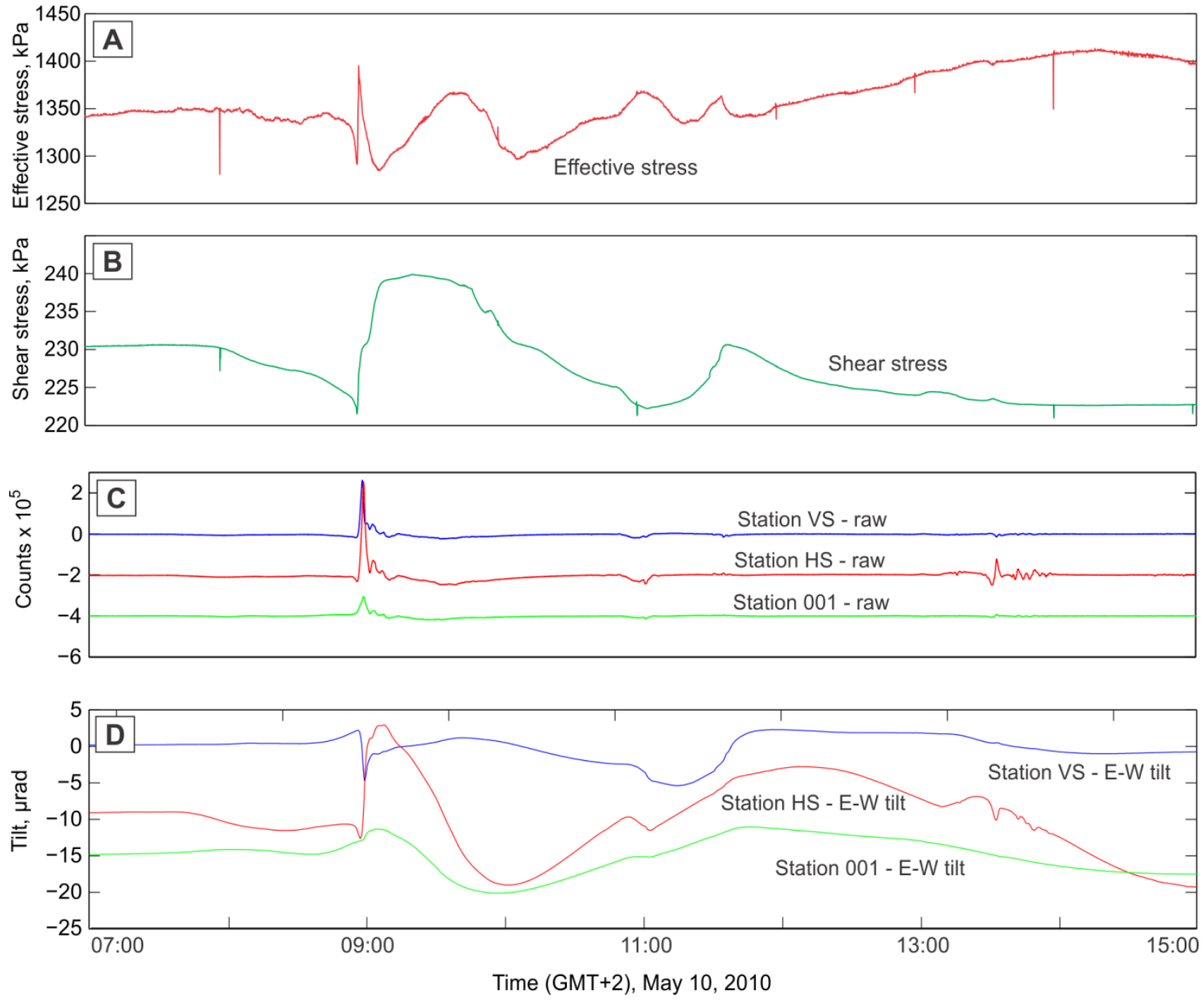

Fig. DR9. Meltwater event of May 15, 2010, as recorded in the friction panel and broadband seismometers. A. Basal effective stress on the panel. B. Shear stress on the panel (a minimum value since only one of two load cells was working at the time). C. Raw E-W component of seismicity for stations VS, HS, and 001 in the research tunnel, low-pass filtered below $1 \mathrm{~Hz}$ and expressed in digital counts. See Fig. DR1 for seismometer locations. D. Tilt magnitude derived from the same components of the broadband seismometers shown in C, band-pass filtered from 100-35,000 s. 